Bulletin of the Transylvania University of Brasov

Series VII: Social Sciences • Law • Vol. 13(62) No. 2 - 2020

https://doi.org/10.31926/but.ssl.2020.13.62.2.22

\title{
THORETICAL ASPECTS IN REGARD TO THE REGULATION OF EVIDENCE IN THE CIVIL LAWSUIT
}

\author{
Cristinel- Ioan MURZEA ${ }^{1}$
}

\begin{abstract}
In our currently used language, the word evidence represents the logical-mental operation by which we attempt to prove something, to demonstrate, to emphasize a certain statement which provides credibility to a particular situation. The institution of evidence in objective law was differently regulated in material law as opposed to procedural law, depending on the different factors which configured private law, but also in direct connection with the lawmaker's interest. Thus, the current Civil Code no longer contains regulations regarding evidence in antithesis with the 1864 Civil Code; however the institution is regulated in the new Civil Procedure Code, namely law no. 134/2010 regarding the Civil Procedure Code, which would later be republished with subsequent changes. As a consequence, the institution is currently studied in Civil Procedure Law, whereas, before this new regulation, it was studied within the general theory of Civil Law.
\end{abstract}

Key words: evidence, documents, expertise, jurisprudence, witnesses

The institution of evidence would be acknowledged and treated differently both by law and by doctrine, by having a certain space and "a different setting among the institutions of civil procedural law".

The semantic attitude of the lawmaker would later determine specialty doctrine to fluctuate in terms of defining this notion, by using several historical constructions such as "Proof of civil law" or more concise "evidence", a term which would be later adopted by most of doctrine. In other works, the institution is known under different titles, but identical in content, as is "proof of specific legal relation", "judicial proof of the specific legal relation" or, in a more synthetic approach "proof of civil rights - evidence".

In conclusion, the quoted authors emphasize that the matter of evidence is used to prove the existence of a certain act or legal fact and thus the birth of a specific civil relation, the basis of a civil subjective right and a correlative obligation.

Among the most consecrated definitions of specialty doctrine is that of the late professor Gh.Beleiu who unequivocally states that "evidence is the legal means used to establish the existence of an act and legal fact and, by that, the civil subjective right and the civil obligation". Other authors have emphasized the meaning of the term

\footnotetext{
${ }^{1}$ Transylvania University of Brasov, Law Faculty, cristinel.murzea@unitbv.ro
} 
"evidence" as well as the task which results from this activity. Thus, O.Căpățână shows that "generically speaking, evidence is a means to establish the truth in regard to facts or legal acts from which the interested party claims certain rights and obligations; specifically, evidence is a means of persuasion effectively used on a certain occasion (a civil lawsuit) in order to establish a deed claimed by the person who aims to valorize a subjective right".

Doctrine was justified to show that the term "evidence" entails three different approaches. In a first hypothesis, the term "evidence" describes the very meaning of the above mentioned definition, in regard to the demonstration of the existence of civil subjective rights as well as correlative civil obligations and the specific civil relation.

In a second opinion, the term "evidence" is specific to the operation of presenting, before a judicial authority, of certain means of proof as "documents, testimonies, confessions, material evidence, expertise" which helps persuade the person who administers the act of justice of the existence of the rights and obligations which are the subject of a trial; thus, the legal phrasing "the plaintiff proves his demands with the use of the following evidence ....".

The third meaning of the term entails the very result of administering evidence as regulated by current laws, which is translated by the expression "the plaintiff proves his claim by ..." or "the defendant proved his innocence by ...."

A similar phrasing by Professor V.M. Ciobanu defines evidence both lato sensu and in a more restrictive manner. Thus, the quoted author widely understood evidence as "the action of establishing the existence or inexistence of a certain fact, legal means by which a certain fact can be proven or established".

In a more restrictive manner, the author showed that evidence tends to demonstrate, by using legal means, the existence of a fact "by proving that a certain material fact is used to prove another material fact". As a consequence, the author distinguishes between main facts - facto probanda, ies probandae - namely facts which form the judicial relation, subject of a trial, which must be proven by evidence - facta probanda res probandaes, namely those who do not exist in the form of a legal relation which is subject to the solving of a court of law and contributes to the demonstration of the existence or non-existence of a fact.

By emphasizing the importance of evidence in specialty doctrine, an undisputable reality was stated, the one according to which subjective law has its own existence, but, by the use of evidence it has a particular color, thus acquiring value if contested. Thus, Professor Aurelian Ionașcu plastically shows that "evidence completes civil subjective rights ad their value depends on the existence of evidence".

However, if legal facts, seen lato sensu, receive different interpretation from subjects of law, the very civil rights generated by those deeds are contested, thus avoiding a litigious matter which would have provided accuracy to the existence or non-existence of the subjective right and civil obligation.

In our opinion, the notion of "evidence" synthetically aims to define the means of evidence used by the parties within the courts of law, in order to prove the existence of the right by documents, witnesses, presumptions, confession from the plaintiff or the defendant, expertise or on scene investigation. 
Thus, the notion of evidence, in its usual form used by law, entails the ensemble of "means which a certain person can use in order to prove and establish, before the court of law, a right that he claims or facts from which a right of the defendant results". A natural consequence of this aspect, the one who claims a right before an authority of the state, will be called upon to prove the legal act of fact which generated the right that he claims. From the time or Roman antiquity, the one who made a claim before a court of law was called upon to prove it according to the well-known principle "actor incumbit onus probatio ei qui dicit, non ei qui negat".

Per a contrario, in lack of any evidence, the legal situations were mere allegations, as the proof, once provided, gave certainty to the right which was subject of the trial. When the right was claimed by two people with contrary interests, the task of proving the claim belonged to the plaintiff, and if the plaintiff invoked the same thing, the trial would become what the Romans called "in excipiendo reus fit actor".

Regardless of who made the claim, he was called upon to "establish the facts or acts which are the source of his right".

By the use of evidence, the parties attempted to convince the judge about the existence of an undisputable reality in regard to the formation of a firm belief in regard to the deed. French doctrine showed that "proving a fact means establishing the reality which is claimed, by demonstrating that the other party is mistaken with elements based on which the judge will form the same belief".

In fact, the existence of the subjective right is attested by its acknowledgement and the fact that it is undisputed by other subjects of law or, on the contrary, if a right is contested, than the person who claims to be the holder of that right, will have to prove, by legal means of evidence, the basis of his claims. Thus, probation induces a certain idea to the judge, that the truth invoked by a party is justified by a credible and undisputable act or fact. In doctrine, this opinion is phrased in the form of an addendum according to which - "To prove is to provide, to the judge, certain elements which will persuade him and justify the truth of the fact claimed by that certain party".

Evidence appears in the field of legal relations when a right or interest of a subject of law is contested and "subjected to a trial between individuals" who demand the court to establish the rightful order violated by the very existence of the right.

Within the legal battle, the parties do no contest the legal fact which generated the subjective right, as their action entails the interpretation of the effects caused by the respective deeds. Each of the parties attempt to persuade the judge of the effect which is more favorable to them in their endeavor to obtain acknowledgement of the right they claim.

It was thus justly stated that "the participants of the legal circuit must only establish the sources of the right they claim, namely the acts and facts which have created the right and the judge will establish their legal consequences, according to the addendum "da mihi factum, dabo tibi jus,.

French doctrine suggestively claimed that "having a right is essential, but being able to prove it is just as essential". As a result, the one "who does not have evidence regarding his right will lose the trial and will be unable to exercise the prerogatives he could have exercised based on his right". 
"Seen in this regard, the role of evidence and of administering it is decisive in regard to the judge's solution, which must be thoroughly motivated and justified as, only by correctly administering evidence, the judge can be made aware of the real relation between the parties, the facts which generated their conflict and thus he will be able to correctly apply the law to that specific case".

The existence and preservation of evidence regarding the existence of the legal fact seen lato sensu - as a generator of the subjective right, will prevent potential litigation which will likely question the existence of the claimed right.

Correctly administered evidence will also form a premise according to which a first solution will be maintained in appeal thus becoming legal and justified. Knowing the truth is the essential purpose of any act of justice, thus ensuring increased security of legal relations between subjects of law.

The activity which valorizes evidence is known as "legal probation and aims to establish, by legally acknowledged means, the acts and facts which created, modified or terminated the legal relation which is subject to litigation" and, on the other hand, "the acknowledgement of the acts and facts in their specific relation with the legal provision, in order to establish the subjective rights and obligations of every party".

Legal probation entails a series of activities such as "filing evidence, their approval by the judge, the presentation of evidence, their acknowledgement by the judge by using his own senses and the appreciation of evidence by valorizing it".

In regard to the evaluation of evidence by the judge, we must mention that the

person called upon to administer the act of justice, along with his endeavor to find out the truth, must also provide a just and balanced appreciation of evidence, he can request the administration of new evidence even if this was not required or does not coincide with the will of any of the parties. Furthermore, article 137 of the Civil Procedure Code mentions that "In case the court is declared incompetent to trial the case, the evidence administered before the incompetent court of law remains filed and will be considered by the competent court; the competent court can request the re administration of evidence for justified reasoning".

Article 250 of the Civil Procedure Code identifies the following means of evidence documents, witnesses, presumptions, confession from one of the parties, made by own initiative of obtained during interrogation, by expertise or by material means of evidence and on scene investigation. Thus, we notice the intention of the lawmaker to provide unified regulation of the evidence, unlike previous regulations in which evidence, in the general meaning of the term, was regulated by the 1865 Civil Code, the Civil Procedure Code and the Commercial Code.

Thus, evidence in the previous Civil Code (Cuza n.n.) was regulated in title III about obligations, chapter IX, titled "About probation of obligations and payment" listing in art. 1170, the fact that any proof will be achieved "by use of documents, witnesses, presumptions, by confession from one of the parties, by oath"; the latter was rescinded by Decree no 205/1950.

In addition to these means of evidence, the old Civil Procedure Code adds expertise and on scene investigation in Book II Title III section III named "Administration of evidence". 
As a special regulation, the Commercial Code in force in 1887 mentioned the following evidence regarding commercial obligation and liberations - authentic acts, privately signed documents, invoices accepted by mail, telegram, financial books provided by the parties, witnesses and other means of evidence accepted by civil law.

As a consequence, we notice that the provisions of the Commercial Code added to common law, namely the Civil Code and the Civil Procedure Code (see article 1 of the Commercial Code and article 721 of the Civil Procedure Code) new means of evidence such as - accepted invoices, telegram, financial books.

We believe that the matter of evidence provides substance and efficiency to subjective civil law and can be invoked even in lack of litigation, as they must not cover just the interests of the parties which would justify their role within substantial law, but they are also useful to the judge, the main actor in administering justice; finally, they harmonize the individual interest with applying public interest regulations which pertain to the act of justice.

Additionally, there is the undisputable argument according to which evidence is mainly defined within procedural law, whose formalism is well known.

In the light of the above mentioned issues, the late professor V.M. Ciobanu unequivocally states that "the institution of evidence is seen as a central institution of the civil lawsuit".

By analyzing the institution of evidence, specialty doctrine elaborated a classification of evidence, based on several criteria.

Thus, if evidence is administered within a trial, it acquires judicial character, as opposed to evidence which is used in a non-contradictory procedure, thus the latter is of extra judiciary character.

We believe that this criterion of classification is one of the most important ones, a premise and argument which caused the matter of evidence to be regulated by procedural law and not substantial law.

Another criterion entails the nature of evidence, depending on which we can distinguish between personal evidence and material evidence. In the first category, we include those facts which express voluntary manifestation, whether positive (statements contained in documents) or negative (destruction of documents). Unlike personal evidence, the material ones are defined by goods which are meant to untangle emphasize and prove the relation which is subject to litigation and its reasons (see presumptions).

In regard to the relations which can be established between them, we distinguish between direct evidence and indirect evidence. The direct ones are meant to prove the existence of the relation which is subject to litigation - the existence of the act which is subject to litigation is proven by a document. Unlike direct evidence, indirect evidence is meant to prove the existence of the relation which is subject to litigation by mere presumption, by a mental operation which derives from a connected fact, in close connection with the fact which is about to be proven.

This criterion considers the fact of whether the proving element contributes or not to proving the main fact. 
Depending on the original or derived criteria, we distinguish between primary evidence - immediate, uncontested and secondary evidence - mediate. In the first category, there are witness statements, presenting a document before the court, whereas in the second category are those regarding what was heard from the statement of another party regarding the situation which generated litigation or presenting a copy of an original document.

A final criteria identified by doctrine led to classification of evidence as those directly perceived by the judge (see on scene investigation) and those in which the facts were perceived by other people (see witness statements).

Specialty doctrine of the so-called "classical age" presented divergent opinions in regard to whether evidence must be complete or not. Famed authors such as Aubry and Rau stated that, in order to legitimate his right, the plaintiff "had to establish and prove every element of fact" of his claim. Opposing the previously mentioned position, M.Planiol and G.Ripert in agreement with the opinions of M. Bartin showed that judicial evidence is never complete, as it represents a probability with greater or reduced credibility.

However, we must mention that what is relevant in regard to forming a certain belief which will materialize in the solution of the judge, does not rest in all the factual elements of the right which will be proven, an endeavor which is impossible, buy only on those elements which are sufficient.

Thus, we agree with the opinion according to which "in reality evidence aims to establish the true meaning of a legal act or material fact which is susceptible of different interpretation". There were several situations in which the plaintiff proved just some elements of a simple fact, thus creating the possibility of the judge to form a series of presumptions - thus, by logical reasoning, other facts were proven.

We must also mention that the institution of evidence in civil matter does not derogate from the time and space enforcement of civil law. In regard to the time enforcement of the legal regulation regarding evidence, two consecrated rules apply: the principle according to which civil law does not regulate for the past and the principle of immediate enforcement of the new civil law. The first rule was regulated from the time of the Romans under the form of the addendum „tempus regit actum, which gave efficiency to the principle of the civil law, namely that is does not regulate for the past, a principle which is also regulated by the Constitution. Thus, according to article 15 second alignment of the Romanian Constitution "The law shall only act for the future, except for the more favorable criminal or administrative law".

The second principle that of the immediate enforcement of the civil law, entails the fact that "once the new law comes into force, it governs all situations which occur after the enforcement of the old law".

As a consequence, the forms of administering evidence are regulated by the law which regulates this matter at the time they are administered.

By strictly applying this rule, the new law will be applied even if the procedure of administering one evidence was performed in accordance with the old law, as nothing prevents the judge "from requesting the re administration of evidence as long as he did not rule on the matter". 
In regard to the space enforcement of the legal regulations regarding evidence, only the situations in which legal relations arise that contain foreign elements, thus generating a conflict of law between Romanian law and foreign law, are of significance.

Until the passing of the new Civil Code, the provisions of Law no 105/1992 regarding the regulation of international private law relations applied a law which had great influence in future regulations. Thus, Law no 105/1992 regarding the regulations of international law relations is currently rescinded and is replaced by Book VII of the Civil Code (Law no 287/2009, articles 2557-2663). Rescinding this law was achieved in two stages - (1) by Law no 71/2011 for the enactment of Law no $287 / 2009$ of the civil Code (see article 230: p ) articles 1-33 and 36-147 (of the 183 articles of the law); (2) by Law no 76/2012 for the enactment of Law no 134/2010 regarding the Civil Procedure Code (see article 83: e) the entire law was rescinded.)

The provisions which regulate lex loci, lex fori, the law chosen by the parties, lex rei sitae will be applied to each particular case. Thus, as an example, we present the following argument - "the means of evidence in order to prove a legal act and the proving power of the document which acknowledges it are those regulated by the law of the place where the legal act was concluded or the law chosen by the parties, if the parties had the right to choose. The facts are proven in accordance with the law of the place where they occurred.

We must mention that in case lex loci or lex fori do not allow other means of evidence, Romanian law will be applied if it allows for other means of evidence. At the same time, the appreciation of evidence, as it is an operation which pertains to the intimate appreciation of the judge, is subject to the law of the forum".

In conclusion, it is undisputed that evidence is of great importance and can only be clarified in regard to the three following aspects: on one hand, it is relevant to the parties but especially for the judge as he must analyze the existence and content of the legal civil relation which is subject to litigation, as the judge will not be able to fundament his decision only on the statements of the parties, which are, most times, not incident in the matter.

In a second regard, evidence provides the premise of the voluntary respect of the subjective right and guarantees the fulfillment of correlative civil obligations "which provides evidence with an important role in protecting subjective rights and preventing civil litigation".

Finally, a subjective right can't be conceived in lack of evidence, which caused doctrine to state that rights must be accompanied - sicut umbra - by correlative evidence. If there is no evidence, the rights are questioned.

Thus, evidence is the means by which we ensure the achievement of subjective civil rights against those who violate it. In lack of evidence, the right does not exist - idem est, non esse aut non probari.

Evidence is meant to prove the existence or non-existence of the legal civil relation which is subject to litigation, thus they are administered during trial, as a general rule, thus resulting in the persuasion of the person called upon to administer the act of justice, namely the judge, who becomes the subject of evidence. In essence, evidence "works on the perception and reasoning capacity of the judge". Based on legal syllogism 
and by interpreting the legal provisions which govern that particular legal relation which is subject to litigation and based on his legal knowledge, the judge will attempt to mentally and cognitively establish the facts. Sometimes the facts are covered by evidence which is more or less conclusive and the judge will be able to rule based on his own beliefs in accordance with his intellectual level, when he "will prove the facts which he a priori considers as pertinent, based on his intuitive legal knowledge".

\section{References}

Beleiu,Gh. (1995). Romanian Civil law. Bucharest: Sansa Publishing House.

Boroi, G. (1993). Civil Procedure Law. Course notes. Bucharest: Romfel Publishing House. Căpățână, O. (1996). Civil law treaty, vol. I. Bucharest: The Academy Publishing House, Ciobanu, V.M. (1997). Theoretical and practical treaty of Civil Procedure, second volume. Bucharest: National Publishing House.

Cosmovici, I. (1993). Introduction in civil law. Bucharest: All Beck Publishing House. Dogaru, I. (1996). Romanian Civil law, Treaty, vol. I. Craiova: Europa Publishing House. Hanga, V. (1998). Latin legal addendums. Bucharest: Lumina Lex Publishing House.

Leș, I. (2001). Comments on the Civil Procedure Code. Bucharest: All Beck Publishing House.

Poenaru, E. (2002). Civil law. General theory. The People. Bucharest: All Beck Publishing House.

Ungureanu, C.T. (2012). Civil law. The General Part. The people. Bucharest: Hamangiu Publishing House.

Urs, I.R. (2015). Civil law, General theory. Bucharest: Hamangiu Publishing House.

***Civil law treaty (1967). Bucharest: The Academy Publishing House. 